\title{
Alyona BUDNIKOVA
}

Minsk State Linguistic University

geronimo1981@mail.ru

\section{FUNCTIONALLY SALIENT FEATURES IN THE SEMANTICS OF LEXICAL ITEMS}

\section{INTRODUCTION}

The problem addressed in this paper is the organisation of semantic features $^{1}$ in the structure of lexical meaning. The perspective taken in the research is a contextual approach to lexical semantics (Lakoff 1987; Langacker 1987; Croft \& Cruse 2004; Evans 2006, 2009; Kharitonchik 2009 etc.) which views the meaning of a word as flexible, open ended and highly sensitive to context. As we shall demonstrate on linguistic data, lexical meaning is a dynamic system of features: it varies in definitions, contextual use and lends different features as bases for the formation of derivatives. In this variety some portions of conceptual information come to the fore more frequently than others due to their greater degree of importance or salience in the meaning structure. Thus, the frequencies of activation of semantic features in three basic types of linguistic environment (paradigmatic, syntagmatic, and derivational) are taken as criteria for assessing their status in the meaning of a word (i.e. their functional salience).

1 "Feature" is used here without any implication that it is an atomic or primitive constituent of the word meaning (cf. Katz \& Fodor 1963). Viewed in this way, features can be factual or mythical, simple or complex, relational or substantive etc. (cf. "attributes" in (Ortony et al. 1985: 570)). 


\section{METHODOLOGY}

The idea that the meaning of a lexical item is composed of a number of semantic units bearing different types of information about the referent triggered a realm of typologies based on differences in their content, function and structural weight.

The content classification of meaning components dates back to the works of J.S. Mill, C. Pierce, G. Frege, F. de Saussure, C.I. Lewis, C.K. Ogden, R. Carnap, I.A. Richards, C.W. Morris, A. Church, W.V.O. Quine etc. who divided the information expressed by a lexical item into two basic types: descriptive (identifying) and evaluative (characterising). Consequently, some features in the structure of word meaning are viewed as "direct" attributes of the denoted object (referential, denotational features etc.) and others - as related to the attitude of language users to it (associative, pragmatic, stylistic features, connotations etc.).

The typology based on the integrating or differentiating function of semantic features in lexical oppositions includes the division into "markers and distinguishers" (J. Katz, P. Postal, J. Fodor), "archisemes and differential semes" (V.G. Gak), "categorial - subcategorial - classifying features" (Z.A. Kharitonchik) etc. Besides, the ability of features to limit the range of syntagmatic contexts of a lexical item can be a treated as their syntagmatic function and become a basis for their classifications (cf. Katz \& Fodor 1963: 199; Coseriu 1967: 293-296; Leech 1977: 25; Pustejovsky 1991: 419).

Finally, the classification of a word's semantic components by their structural weight grades them as more and less central according to different criteria. On one hand, as the source of semantic features in lexical meaning is primarily the referent and the "world-knowledge" associated with it, they can be classified by their essentiality (i.e. ability to determine the exterior or function of the denoted object), necessity for category membership, occurrence within all category members, vividness among other features, entrenchment in speakers' minds in relation to the referent etc. (Rosch 1978: 38; Cruse 1986: 16; Langacker 1987: 159; Nikitin 1988: 51-52; Pattabhiraman 1992: 30-39; Sloman et al. 1998: 190; Ahn et al. 2000: 362). These are criteria for structuring the features of a designated entity in terms of their psychological salience, which is studied by means of psycholinguistic experiments where informants either enumerate the features of the denoted object and grade them according to their impor- 
tance or perform various tasks aimed at comparing the objects and, thus, profiling their more salient properties.

On the other hand, there is a linguistic way to reconstruct the organization of semantic features in the meaning of a word, i.e. taking into account the degree of their activation in different aspects of its functioning: as an element in the language system, in context, and in the formation of semantically derived units.

\subsection{PARADIGMATIC SALIENCE}

Semantic features salient paradigmatically in the meaning of a word are the ones that help language users differentiate the denoted class of objects from other classes. This can be revealed not only by experimental methods (Rosch 1978: 32) but also with the help of lexicographic sources. To describe the meaning of a word various lexicographic definitions often differ in their choice of features (e.g. "necessary and sufficient" vs. prototypical ones), which allows the evaluation of the paradigmatic salience of features by calculating the frequency of their lexicographic profiling. This is close to what J. Bybee refers to as the "type frequency" (i.e. dictionary frequency) of a particular formal pattern (e.g. a stress pattern, an affix, or a consonant cluster) (Bybee 2003: 12). The difference, though, is that formal patterns with high type frequency tend to be more productive in speech or word formation, whereas the dependence of lexicographic salience of this or that feature in lexical meaning and its frequency of profiling in context or derivation is still to be revealed. Thus, the first criterion of functional salience of semantic features in the meaning of a word in our research is the frequency of their activation in a variety of its dictionary definitions.

\subsection{SYNTAGMATIC SALIENCE}

The syntagmatic salience, as pointed out by D. Geeraerts, is the typicality of the syntagmatic frames or contexts of a lexical unit (Geeraerts 2006: 82). For instance, the use of the frame the apple is in the bowl is more typical as an expression of containment than, say, the jelly pie is in the suitcase (even though the containment relation itself is the same as in the typical case) (ibid.). In other words, for the referents of the units bowl and suitcase as containers the salient contents are different, and this is revealed syntagmatically. 
The notion of syntagmatic salience can well be applied to the analysis of lexical meanings. Since the meaning of a word used in context is a product of "dynamic construal" (Croft \& Cruse 2004: 75) consisting partly of well-entrenched "association between the word and the designated conceptual sphere" (Kharitonchik 2009: 120) and of "contextinduced semantic contributions" (Evans 2009: 71), different contexts tend to highlight some of its features and suppress others. For example, in the sentence 'My fault,' said Nick as a big, yellow dog bounced through the door [A0R 2123] $]^{2}$, the meaning of the word dog is modified by perceptual ('size'; 'colour') and locative features ('moving/locomotion'), and in the context Lucy Lane, trying to make contact, got up and stooped over the $\operatorname{dog}$ [HWP 2842], the foregrounded feature in the meaning of dog is 'location/place'. Thus, the syntagmatic (or contextual) salience of semantic features, i.e. the frequency of their activation in a vast corpus in connection to the entity denoted by the given word (cf. "token frequency" of an item in (Bybee 2003: 11)), is viewed in this research as the second criterion of their functional salience in the structure of lexical meaning.

\subsection{DERIVATIONAL SALIENCE}

One more source of information about the salient (and, thus, more frequently profiled) constituents of the meaning of a word is its metaphorical derivatives with transparent motivations. As L. Janda points out, "like the prototype, metaphor is motivated by relevant information that is salient in human experience; it highlights some facts about the target domain, but hides others" (Janda 2010: 17). Consequently, a range of metaphorical derivatives of an item will show what types of information in its primary referent (source domain) are absorbed into the "blended space" created by a metaphor and are used to describe the secondary referent (target domain). So, the third criterion of the functional salience of semantic features used in this research is the frequency of their profiling via metaphorically derived units of a lexical item.

2 The sentences were taken from the British National Corpus (BNC). The code corresponds to the relevant text and the number of the sentence in it. 


\section{RESEARCH}

The suggested methodology was applied to some common English animal names like bird, cat, dog, horse, fish, owl, mouse, and their hyperonym creature. The componential analysis of their descriptions in 10 English dictionaries ${ }^{3}$ revealed that to define the meanings of these words lexicographers rely on a limited number of features grouped in 10 aspects (see Table 1).

As the data show, in the lexicographic profiles of the given items there are from 1 to 3 constant differential features (with the frequency of $100 \%$ ) which, thus, can be considered the most salient semantic components together with the nuclear classifying features, expressed by the words animal, creature, organism etc. and not included in the present study ${ }^{4}$. In the meanings of the majority of the items the most salient features from the paradigmatic point of view are perceptual ones (e.g. for bird, fish, horse, mouse, owl), though the frequency of their realisation may vary from definition to definition. For the hyperonym creature constant features in its lexicographic profiles are biological ones as, for example, 'animateness' in the definition 'anything that lives except plants' (MD). The definitions of cat, dog, and horse which form the class of names of domestic animals rely on their constant utilitarian properties. Finally, the item owl has 3 types of features with 100\% salience in its definitions: perceptual (large eyes) and temporal + behavioural (nocturnal/hunts at night etc.).

One of the main questions for the next stage of the research is whether the features relevant paradigmatically in the meaning of a word are also in demand in its contextual realisation, or the context mostly profiles types of information other than the ones fixed in definitions.

The contexts for the study ${ }^{5}$ were taken from the British National Corpus (BNC), and in the cases of mouse, owl, and creature (with fewer than 2000 relevant contexts in the BNC) - both from the BNC and free

3 The references include only the lexicographic sources cited in the article.

4 To ensure objective comparison of the definitions, all the classifying words were unified, i.e. narrow classifiers (e.g. mammal etc.) were reduced to wider terms such as animal, organism etc. with additional features (e.g. 'milk feeding' etc.) considered as profiled by these classifiers.

5 In a number of cases the context was not sufficient for the realization of a particular aspect in the meaning of the studied words (e.g. There is an old Middle Eastern story about a frog (in some versions it is a fish) ... [HRE 152]). Besides, idiomatic expressions were also excluded from this stage of analysis (only to address them later). 
TABLE 1. The paradigmatic salience of semantic features in the meanings of the studied animal names

\begin{tabular}{|c|c|c|c|c|c|c|c|c|}
\hline \multirow[b]{2}{*}{ Semantic features } & \multicolumn{8}{|c|}{ Relative lexicographic frequency, $\%$} \\
\hline & 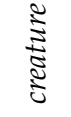 & $\stackrel{2}{2}$ & $\vec{\Xi}$ & \& & i & $\begin{array}{l}\varpi \\
\vdots \\
\vdots\end{array}$ & $\begin{array}{l}\stackrel{\Xi}{\mathfrak{\Xi}} \\
\stackrel{\Xi}{\Xi}\end{array}$ & న్రి \\
\hline $\begin{array}{l}\text { Perceptual (size, external body parts, } \\
\text { colour, shape, sound, tactile characteristics) }\end{array}$ & 10 & 100 & 90 & 60 & 100 & 100 & 100 & 100 \\
\hline $\begin{array}{l}\text { Biological (animateness, physiological state, } \\
\text { biological processes, gender) }\end{array}$ & 100 & 80 & 40 & 30 & 80 & 70 & 60 & 20 \\
\hline $\begin{array}{l}\text { Systematising (taxonomic name, relation } \\
\text { to other species, size of the population) }\end{array}$ & 20 & 40 & 60 & 90 & 60 & 50 & 50 & 50 \\
\hline $\begin{array}{l}\text { Utilitarian (domesticity, function in relation } \\
\text { to man) }\end{array}$ & & & 100 & 100 & & 100 & & \\
\hline $\begin{array}{l}\text { Locative (habitat, locomotion, existence } \\
\text { in the real world) }\end{array}$ & 50 & 50 & & & 100 & 10 & 40 & 10 \\
\hline Constitutive (internal body parts) & & & & & 50 & & & \\
\hline Temporal (age, stages of development etc.) & & & 30 & 10 & & 50 & & 100 \\
\hline Behavioural (habitual behaviour) & & & 20 & 10 & & 10 & & 100 \\
\hline Psychological $^{4}$ (character) & & & & 10 & & 10 & & \\
\hline Social (symbol in the society) & & & & & & & & 10 \\
\hline
\end{tabular}

electronic sources. The range of word combinations under analysis are of four basic structural types: noun phrases and predicative phrases with the studied words as heads (e.g. the lean-flanked wild and free horse [A0L 3852]; the cat curled up against his feet [FPB 618]), noun phrases with the studied words as modifiers (e.g. bird droppings [ADA 1675]; the normal life span of the mouse [EA0 1103]), verb phrases with the studied

6 Psychological properties attributed to animal names (dog and horse) are certainly drawn out of the instinctual behaviour of the corresponding animals and may not have a biological basis. However, they were not excluded from the list as they contribute to the general image of the referents from the lexicographic perspective. 
words as arguments (e.g. remember to pat the dog [CJE 553]; swooping in from behind the owl [BLX 1644]), and phrases with subordinate clauses attributive to the studied words (e.g. The wave is a fish that always gets away [ASV 82]; It is the occasional unknown specimen which can prove unnerving, the creature which has never been seen before in any swamp or tropical rainforest... [AKE 155]).

As the contextual analysis shows, though the variety of features, their combinations within the aspects and cross-aspectual combinations are certainly greater in context than definitions, the typological range of features that come to the fore in contextual use and lexicographic discourse is the same (10 aspects) (see Table 2 below). Moreover, there are practically no cases when the features found in the definitions are not profiled in context.

In the majority of cases (49\%, unmarked in Table 2$)$, the information profiled in context consists partly of the features also fixed in the dictionaries and partly of the features irrelevant for definitions. This type of correlation is found in all the aspects but mostly among perceptual and biological features. Besides, the frequency of contextual activation of these properties differs from noun to noun. While for the meanings of some words the features profiled only in context are much more frequent than the ones fixed both in definitions and context (e.g. perceptual features in the meanings of creature and fish; biological features in bird, cat, fish, mouse, dog; locative features in mouse, owl, etc.), for others the reverse is true (e.g. perceptual features in the meanings of bird, cat, owl; biological features in creature, locative features in fish, etc.).

In $12.5 \%$ of all cases (marked light grey in Table 2 ) the features realised in context are the same or even less varied than in the dictionaries, which is specific primarily in the systematising aspect. Being quite infrequent in context, these features, however, are often salient paradigmatically (see Table 1).

The remaining $38.5 \%$ are cases when contextually profiled features bear the information not fixed in the lexicographic sources (cases marked dark grey in Table 2). Most often this information is not frequent in context, but there are a few exceptions. For example, the locative features of cat and $\operatorname{dog}$ (esp. 'moving/locomotion', 'place/location'), constitutive features of mouse (esp. 'internal body parts'), and behavioural features of creature (esp. 'concrete actions') are characterized by quite high contextual frequency along with their lexicographic irrelevance. The variability 
TABLE 2. The correlation of syntagmatic salience and lexicographic representation of semantic features in the meanings of the studied animal names

\begin{tabular}{|c|c|c|c|c|c|c|c|c|c|}
\hline \multirow{2}{*}{ 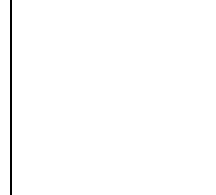 } & \multirow{2}{*}{ Semantic features } & \multicolumn{8}{|c|}{ Relative contextual frequency, \% } \\
\hline & & 章 & $\stackrel{5}{5}$ & $\vec{z}$ & $\frac{80}{d}$ & 鸟 & $\begin{array}{l}\text { ळ } \\
\vdots\end{array}$ & $\begin{array}{l}\stackrel{\Xi}{\Xi} \\
ミ \\
\Xi\end{array}$ & $\widetilde{\Xi}$ \\
\hline \multirow{2}{*}{ Perceptual } & Profiled in definitions and context & 6.4 & 32.5 & 20.0 & 13.6 & 6.4 & 15.5 & 12.0 & 42.7 \\
\hline & Profiled only in context & 18.1 & 11.1 & 8.6 & 15,0 & 23.1 & 12.3 & 10.6 & 2.2 \\
\hline \multirow{2}{*}{ Biological } & Profiled in definitions and context & 15.0 & 3.4 & 4.7 & 1,3 & 3.2 & 11.8 & 8.1 & 4.8 \\
\hline & Profiled only in context & 4.6 & 10.1 & 14.8 & 13.0 & 16.1 & 8.2 & 15.2 & 8.7 \\
\hline \multirow{2}{*}{ Systematising } & Profiled in definitions and context & 0.9 & 1.0 & 1.2 & 0.7 & 0.8 & 0.4 & 0.4 & 5.2 \\
\hline & Profiled only in context & 0 & 0 & 0 & 0 & 0 & 0 & 0 & 0 \\
\hline \multirow{2}{*}{ Utilitarian } & Profiled in definitions and context & 0 & 0 & 6.9 & 3.4 & 0 & 2.3 & 0 & 0 \\
\hline & Profiled only in context & 3.7 & 5.7 & 11.3 & 19.5 & 7.3 & 17.3 & 6.4 & 6.3 \\
\hline \multirow{2}{*}{ Locative } & Profiled in definitions and context & 7.8 & 13.2 & 0 & 0 & 22.0 & 17.2 & 5.3 & 4.6 \\
\hline & Profiled only in context & 12.8 & 16.8 & 28.0 & 30.9 & 9.0 & 18.6 & 20.6 & 14.9 \\
\hline \multirow{2}{*}{ Constitutive } & Profiled in definitions and context & 4.6 & 1.8 & 0 & 0 & 2.2 & 0 & 0 & 0 \\
\hline & Profiled only in context & 1.8 & 0.6 & 2.6 & 1.6 & 8.1 & 3.0 & 13.5 & 0.2 \\
\hline \multirow{2}{*}{ Temporal } & Profiled in definitions and context & 0 & 0 & 2.6 & 4.5 & 0 & 1.8 & 0 & 0.6 \\
\hline & Profiled only in context & 1.2 & 1.9 & 0.1 & 0 & 2.2 & 0.3 & 6.7 & 2.6 \\
\hline \multirow{2}{*}{ Behavioural } & Profiled in definitions and context & 0 & 2.7 & 6.0 & 2.9 & 0 & 4.1 & 0 & 2.8 \\
\hline & Profiled only in context & 15.6 & 10.1 & 6.7 & 8.4 & 9.7 & 13.9 & 5.6 & 13.1 \\
\hline \multirow{2}{*}{ Psychological } & Profiled in definitions and context & 0 & 0 & 0 & 5.6 & 0 & 5.3 & 0 & 0 \\
\hline & Profiled only in context & 6.7 & 4.5 & 8.2 & 1.7 & 1.2 & 6.1 & 3.5 & 3.0 \\
\hline \multirow{2}{*}{ Social } & Profiled in definitions and context & 0 & 0 & 0 & 0 & 0 & 0 & 0 & 1.2 \\
\hline & Profiled only in context & 0.9 & 0.4 & 3.2 & 2.5 & 0 & 0.9 & 0.7 & 0 \\
\hline
\end{tabular}

of these features makes them irrelevant for definitions, but in context they are in demand due to, first, the nature of the referents of the corresponding words (animate things able to move, act etc.) and, second (in the case 
of mouse), their importance to man (the wide use of mice in medicine results in the high frequency of the contextual profiling of constitutive features in the meaning of the word mouse).

Since the number of features profiled in a lexicographic definition is normally higher than in a single context with the corresponding word, the average lexicographic frequency is higher than the contextual one. Thus, while the upper limit of paradigmatic salience is $100 \%$ of lexicographic frequency, the upper limit of syntagmatic salience is only $40 \%$ of contextual frequency. To see the correlation of these data, we compared not the actual frequencies, but the relative salience of features in definitions and context.

TABLE 3. The correlation of paradigmatic and syntagmatic salience of semantic features in the meanings of the studied nouns

\begin{tabular}{|l|c|c|}
\hline & $\begin{array}{c}\text { Features salient paradigmatically } \\
(80-100 \%)\end{array}$ & $\begin{array}{c}\text { Features salient syntagmatically } \\
(20-40 \%)\end{array}$ \\
\hline creature & biological & perceptual, locative \\
\hline bird & perceptual, biological & perceptual, locative \\
\hline cat & perceptual, utilitarian & perceptual, locative \\
\hline dog & systematizing, utilitarian & perceptual, utilitarian, locative \\
\hline horse & perceptual, utilitarian & perceptual, biological, locative \\
\hline fish & perceptual, biological, locative & perceptual, locative \\
\hline mouse & perceptual & perceptual, biological, locative \\
\hline owl & perceptual, temporal, behavioural & perceptual \\
\hline
\end{tabular}

As seen in Table 3, for the overwhelming majority of nouns there are types of features in their meanings that are salient from both perspectives. Most often they are perceptual ones (in 6 out of 8 cases). However, the types of knowledge other than perceptual information about the referents most often do not correlate in their paradigmatic and syntagmatic salience.

The next stage of the research is to show what types of features in the meanings of the animal names under consideration are evoked by a metaphorical shift, and to evaluate their derivational salience. The analysis of metaphorical expressions includes stating the "literal" and 
transferred meaning of a word or phrase, the constituents of both that are being mapped by the metaphor, and the semantic links between them (Lakoff \& Turner 1989: 170-191; Geeraerts 2006: 200), often with the help of various etymological sources ${ }^{7}$.

As the study shows, in the majority of examples (166 out of 263 cases) from the metaphorical corpus the semantic links between the primary and secondary referents are common or similar features of the two. For example, the derivatives fish bellied '(of a beam or rail) having a convex underside' (RHD), dog 2 'any of various hooked or U-shaped metallic devices used for gripping or holding heavy objects' (AHDEL), and eat like a bird 'to eat sparingly' (RHD) are based on common features of the primary and secondary referents ('shape' + 'external body parts' in fish bellied, 'gesture's in $\operatorname{dog} 2$, 'eating habits' in eat like a bird). In a number of cases the common features are not substantive but relational, i.e. relations among the constituents of the primary referent are mapped onto the constituents of the secondary referent. For example, in the idiom better be the head of a dog than the tail of a lion 'it is better to be the leader of a less prestigious group than to be a subordinate in a more prestigious one' (McGraw-Hill) the relation of a dog's head to the rest of the body is mapped onto the relation of a person to the rest of the group. In other words, the relational constitutive feature 'parts in relation to the whole' common to both the referents serves as a semantic link between the "literal" and transferred meanings of the phrase.

The metaphorical shift in the expression the owl thinks all her young ones beauties 'said to mean that parents think that their children are faultless' (retrieved from http://www.weblearneng.com/owl-figures-ofspeech, accessed August 17, 2015), like in the examples above, is based on the features viewed as common between the two referents, but this time the features are not only "real" to the referent owl, but also associative: the phrase portrays a mother owl with her young, though not very beautiful, and adds human thinking ability to this image. These cases are quite rare in the metaphorical corpus, with only 5 examples.

\footnotetext{
7 Expressions based on connotation with lost or implicit referential bases were excluded from the study (e.g. 'inferiority' in every dog has its day, try it on the dog, 'extremity' in dogcheap, 'pretentiousness' in put on the dog (dress up formally), 'wrongness' in a dog cabbage, a dog lily, dog's parsley etc.).

8 This feature is viewed as a combination of 'concrete action' + 'external body parts'.
} 
In 24 metaphorical derivatives the semantic link between the referents is a feature of the secondary referent ascribed to the primary referent without addressing the features of the primary referent as such ${ }^{9}$ (e.g. the human feature 'behaviour: abusing alcohol' to the referent fish in the idiom drink like a fish 'to drink alcoholic beverages to excess' (RHD)).

Finally, in 68 examples a feature of the primary referent is fixed in the "literal" meaning of the phrase and makes the basis for a further association with a feature of the secondary referent. For instance, in the expression be like a dog with a bone the profiled feature of the referent dog is 'habitual behaviour: [gnawing on] a bone', which is associated with a human feature 'mental capacity: thinking about something all the time'. Due to this association it is possible to map the image of a dog onto a human being in this expression. However, unlike in the idiom the owl thinks all her young ones beauties, the human feature of mental capacity is not attributed directly to the primary referent of $d o g$ and, thus, is not considered as profiled in the context be like a dog with a bone.

As for the thematic range of the profiled features in metaphorical contexts, it is essentially the same as in definitions and context, including not only the perceptual and frequently observable behavioural properties of the referents, but also biological (e.g. 'eating habits', 'sleeping habits', 'physical abilities'), locative (e.g. 'moving/locomotion', 'habitat'), constitutive (e.g. 'parts in relation to the whole', 'internal body parts'), psychological (e.g. 'character', 'mental capacity'), utilitarian (e.g. 'function in relation to man'), and temporal (e.g. 'age') features (see Table 4 below). The most productive of all the studied words in the formation of metaphorical derivatives is the item dog with 54 relevant examples, and the least productive one - the hyperonym creature ${ }^{10}$ ( 0 examples).

In general, though the most frequent features profiled by metaphors in all the meanings of the animal names under consideration are perceptual ones, their relative salience differs from word to word. For example, while perceptual features in the meaning of the word mouse are

\footnotetext{
9 Though associative features are probably motivated by some properties of the primary referent (e.g. the open-mouthed taking in of water of the fish to obtain oxygen as a motivation for the idiom drink like a fish), the latter are not taken into account as vague and ambiguous.

10 The derivatives of this word are not metaphorical: creature 2 'a human being, in pity, contempt, or endearment; a servile dependent; an instrument; a tool (WRUD), creature comfort(s) 'things that contribute to bodily comfort and ease, as food, warmth, a comfortable bed, hot water for bathing, etc.' (RHD).
} 
profiled in $78.1 \%$ of its derivatives (in 25 out of 32 cases), for bird, cat, and $\log$ these figures are much lower $-47.6 \%$ (in 20 out of 42 ), $47.2 \%$ (in 25 out of 53), and 50\% (in 27 out of 54 cases), respectively, owing to the high frequency of other features in their meanings, i.e. locative properties for bird (e.g. a bird of passage 'a person who moves from place to place frequently' (AHDEL)) and behavioural ones for cat and dog (e.g. put the cat among the pigeons 'to introduce some violently disturbing new element' (CED); a dogfish 'a name for various types of small shark. Said to be so called because they hunt in packs' (OED)).

TABLE 4. The salience of semantic features in the meanings of the studied animal names as profiled by their metaphorical derivatives

bird cat dog fish horse mouse owl

\begin{tabular}{|c|c|c|c|c|c|c|c|}
\hline \multirow[b]{2}{*}{$\begin{array}{l}\text { Semantic features profiled } \\
\text { in metaphorical contexts }\end{array}$} & \multicolumn{7}{|c|}{ Absolute frequency } \\
\hline & 5 & $\vec{\Xi}$ & 8 & क्र & ڤ్ & @્ & $\bar{\Xi}$ \\
\hline Perceptual & 20 & 25 & 27 & 17 & 25 & 25 & 12 \\
\hline Biological & 4 & 4 & 4 & 1 & 5 & 0 & 2 \\
\hline Utilitarian & 2 & 1 & 7 & 3 & 10 & 2 & 0 \\
\hline Locative & 9 & 7 & 4 & 3 & 1 & 1 & 0 \\
\hline Constitutive & 3 & 2 & 4 & 1 & 2 & 0 & 0 \\
\hline Temporal & 3 & 2 & 3 & 0 & 2 & 0 & 7 \\
\hline Behavioural & 2 & 14 & 12 & 0 & 3 & 2 & 7 \\
\hline Psychological & 4 & 11 & 4 & 2 & 3 & 2 & 5 \\
\hline Social & 3 & 1 & 1 & 2 & 1 & 1 & 0 \\
\hline Contexts all in all & 42 & 53 & 54 & 28 & 39 & 32 & 22 \\
\hline
\end{tabular}

\section{DISCUSSION}

As seen from the examples above, the features profiled in all the studied types of linguistic environment differ not only by their frequencies but also by their degrees of necessity in the meaning structures. If 
we apply the idea of D.A. Cruse (Cruse 1986: 16-20), they can be divided into expected (features, present in all or the majority of category members), possible (variable properties that characterise some of the category members), unexpected (not typical but virtually possible characteristics of the class), and excluded (impossible for the category members). For example, most of the activated perceptual features are either expected or possible for the referents of the studied animal names, such as the complex feature 'shape' + 'external body parts' profiled in the meaning of the word fish by its derivative fish bellied, or 'external body parts' in the meaning of cat in the context Georgina came back with a grey rag, sat down and watched her brother poke his fingers in the cat's ears [A73 1243]. However, there are examples of exaggerations of perceptual properties, mostly found in metaphorical contexts, e.g. in the idiom like a dog with two tails 'to be very happy' (CID). In suchlike cases the profiled features are either unexpected or excluded.

In all the types of context for the studied nouns (paradigmatic, syntagmatic, and derivational) the most salient are expected and possible features, though quite a number of idiomatic expressions, like the example above, exploit unexpected and excluded features of the primary referents. In this respect psychological features constitute a borderline case between possible and impossible information attributed to the referents of animal names. On one hand, such psychological features as 'character' and 'emotional state' are quite often used as characteristics of the animal referents in free and idiomatic contexts and even definitions: e.g. 'the horse excels in strength, speed, docility, courage, and nobleness of character ...' (WRUD). They do not seem inappropriate or excluded for the studied classes of animals, though their salience is definitely greater in the meanings of cat, dog, and horse than fish, mouse, creature, etc. On the other hand, the feature 'mental capacity' attributed to the referents of the animal names may be viewed as already a deviation from the norm (e.g. in the idiom the owl thinks all her young ones beauties) or obviously a human feature ascribed to an animal (e.g. wise as an owl 'very wise' (McGrawHill)).

The information about the referents of the studied names fixed in lexicographic sources and activated in context and metaphorical derivation may also be divided into perceptual vs. conceptual types (Pattabhiraman \& Cercone 1990: 80), i.e. external characteristics such as size, sound, colour etc. vs. shared experiential knowledge about the denoted object such as 
habitat, symbol in the society etc. In this respect the most salient features in all the taken contexts are conceptual ones which include all that is known about the referents apart from their external characteristics.

Finally, the classification of profiled features can go along the line of categorial (Rosch 1978; Sloman et al. 1998: 192) vs. conceptual centrality (Sloman et al. 1998: 191; Keil et al. 2002: 380), i.e. prototypical features, central for the denoted category (e.g. 'external body parts: having whiskers, fur, a tail, etc.', 'function in relation to man: kept as a pet, etc.' for cat) vs. features relevant in the classification of the corresponding referents as natural kinds (e.g. 'taxonomic name: Felis catus', 'biological properties: warm-blooded, carnivorous, etc.' for cat). This division is most vivid in lexicographic definitions some of which rely on conceptual centrality (e.g. dog 'a highly variable domestic mammal (Canis familiaris) closely related to the gray wolf' (MWOD)) and others - on the categorial centrality of properties (e.g. dog 'a common animal with four legs, fur, and a tail. Dogs are kept as pets or trained to guard places, find drugs, etc.' (LDOCE)).

\section{CONCLUSION}

The types of conceptual knowledge chosen for the defining purposes of the studied animal names are practically the same as the ones profiled in various contexts of their use. However, the frequency and, thus, salience of them differs, largely due to the lexicographic orientation on the typical rather than accidental and the utilitarian bias in the definitions. As the studied names are identifying rather than characterising, their definitions rely largely on the exterior of the typical referent. As they are natural kind terms, their lexicographic descriptions tend to include biological and systematising information, central in biological classifications of the referents.

The contextual frequency of semantic features primarily depends on the type of classifier they surround. Since the studied names belong to the class of physical objects, but not artifacts, they are most often described in context in relation to their exterior and location in space, rather than function and internal parts. Since they are animate things, but not plants, they can be attributed some behavioural properties (e.g. 'concrete actions') and dynamic locative characteristics (e.g. 'moving/locomotion'). 
Moreover, both lexicographic profiles and contextual realisations of the studied names reveal the proximity of their referents to humans, which, first, shows in the different weights of utilitarian features in definitions and in context for different animal names (cf. $\operatorname{dog}(100 \%$ in definitions, $22.9 \%$ in context) and owl ( $0 \%$ in definitions, $6.4 \%$ in context)) and, second, explains the high contextual frequency of some other features, like 'size' for fish as its important utilitarian parameter ( $14.8 \%$ in context).

Though the aspects of meaning of the studied nouns profiled in definitions and context are the same, in the majority of cases the choice of features within the aspects and their frequencies differ. Thus, in general, the lexicographic and contextual sources of semantic features in the meanings of the studied nouns can be characterised as mutually complementary.

The most numerous among metaphorical derivatives are models with similar features or similar relations among the constituents of the primary and secondary referents which profile expected or possible features for the referents of the studied animal names. At the same time, there are also cases with associative semantic links between the referents, excluded in the semantic structure of the primary meanings. Thus, although the main criteria for choosing this or that property to be profiled in metaphorical contexts are its typicality and vividness among other properties of the primary referent, the relevance of a feature in the description of human beings is also addressed, allowing not only borrowing animal-specific attributes to characterise people, but also sharing human-specific attributes with animals.

\section{REFERENCES}

Ahn, Woo-kyoung, Nancy S. Kim, Mary E. Lassaline, Martin J. Dennis. 2000. "Causal status as a determinant of feature centrality". Cognitive Psychology $41,361-416$.

Bybee, Joan. 2003. Phonology and Language Use. Cambridge: Cambridge University Press.

Coseriu, Eugenio. 1967. "Lexikalische Solidaritäten". Poetica 1: 293-303.

Croft, William and D. Alan Cruse. 2004. Cognitive Linguistics. Cambridge: Cambridge University Press.

Cruse, D. Alan. 1986. Lexical Semantics. Cambridge etc.: Cambridge University Press.

Evans, Vyvyan. 2006. "Lexical concepts, cognitive models and meaning-construction". Cognitive Linguistics 17/4, 491-534. 
Evans, Vyvyan. 2009. How Words Mean: Lexical Concepts, Cognitive Models and Meaning Construction. Oxford: Oxford University Press.

Geeraerts, Dirk. 2006. Words and other Wonders: Papers on Lexical and other Topics. Berlin, New York: Mouton de Gruyter.

Janda, Laura A. 2010. "Cognitive linguistics in the year 2010". International Journal of Cognitive Linguistics 1/1, 1-30.

Katz, Jerrold J. and Jerry A. Fodor. 1963. "The structure of a semantic theory". Language 39/2, 170-210.

Keil, Frank, Nancy S. Kim, Marissa L. Greif. 2002. "Categories and levels of information". In Forde, Emer M. E. (ed.) Category Specificity in Brain and Mind. Hove: Psychology Press, 375-401.

Kharitonchik, Zinaida. 2009. "Lexical meaning as a dynamic entity of variant semantic components". Probleme Actuale de Lingvistică, Glotodidacticăşi Ştinţă Literară: actele colocviului internaţional IV/I, Chişinău, 113-121.

Lakoff, George. 1987. Women, Fire, and Dangerous Things. What Categories Reveal about the Mind. Chicago, London: University of Chicago Press.

Lakoff, George and Mark Turner. 1989. More than Cool Reason: a Field Guide to Poetic Metaphor. Chicago, London: University of Chicago Press.

Langacker, Ronald W. 1987. Foundations of Cognitive Grammar: Theoretical Prerequisites. Stanford: Stanford University Press.

Leech, Geoffrey. 1977. Semantics. Harmondsworth, New York: Penguin Books.

Nikitin, Mikhail. 1988. Osnovy Lingvističeskoj Teorii Značenija. Moscow: Vysshaja Shcola.

Ortony, Andrew, Richard J. Vondruska, Mark A. Foss, Lawrence E. Jones. 1985. "Salience, similes, and the asymmetry of similarity". Journal of Memory and Language 24, 569-594.

Pattabhiraman, Thiyagarajasarma. 1992. Aspects of Salience in Natural Language Generation. PhD thesis, School of Computing Science, Simon Fraser University, Burnaby, BC, Canada.

Pattabhiraman, Thiyagarajasarma and Nick Cercone. 1990. "Selection, salience, relevance and the coupling between domain-level tasks and text planning". $V$ International Workshop on Language Generation: proceedings, Pittsburgh, 7986.

Pustejovsky, James. 1991. "The generative lexicon”.Computational Linguistics 17/4, 409-441.

Rosch, Eleanor. 1978. "Principles of categorization". In Rosch, Eleanor and Barbara B. Lloyd (eds.) Cognition and Categorization. Hillsdale: Lawrence Erlbaum, 27-48.

Sloman, Steven A., Bradley C. Love, Woo-kyoung Ahn. 1998. "Feature centrality and conceptual coherence". Cognitive Science 22/2, 189-228. 


\section{DICTIONARIES AND TEXT SOURCES}

AHDEL - The American Heritage Dictionary of the English Language. 2015. Houghton Mifflin Harcourt. https://www.ahdictionary.com.

CED - Collins English Dictionary. 2012. Complete and Unabridged. HarperCollins Publishers. http://dictionary.reference.com.

CID - Cambridge Idioms Dictionary. 2006. Cambridge University Press. http:// idioms.thefreedictionary.com.

LDOCE - Longman Dictionary of Contemporary English. 2015. Pearson Education Limited. http://www.ldoceonline.com

McGraw-Hill - McGraw-Hill Dictionary of American Idioms and Phrasal Verbs. 2002. The McGraw-Hill Companies, Incorporated. http://www.thefreedictionary. com.

MD - Macmillan Dictionary. 2015. Macmillan Publishers Limited. http://www. macmillandictionary.com.

MWOD - Merriam-Webster Online Dictionary. 2015. Merriam-Webster, Incorporated. http://www.merriam-webster.com.

OED - Online Etymology Dictionary. 2015. Douglas Harper. http://www.etym online.com.

RHD - Random House Dictionary. 2015. Random House, Incorporated. http:// dictionary.reference.com.

The British National Corpus, 2007. XML Edition (9 GB). Oxford University Computing Services on behalf of the BNC Consortium.

WRUD - Webster's Revised Unabridged Dictionary. 1913. DICT Development Group. http://www.dict.org.

\section{FUNCTIONALLY SALIENT FEATURES IN THE SEMANTICS OF LEXICAL ITEMS}

\section{Summary}

The aim of the present research is to work out and test a model of lexical meaning in terms of the functional salience of its constituents, i.e. the frequency of profiling of semantic features in different aspects of word functioning: as an element in the language system (paradigmatic salience), in context (syntagmatic salience), and in the formation of derived units (derivational salience). These parameters, viewed as objective criteria to assess feature weights, are used to reconstruct the organization of semantic features in the meanings of some common English animal names.

Key words: functional salience, lexical meaning, feature weights, profiling 


\section{CECHY FUNKCJONALNIE WYRAZISTE \\ W SEMANTYCE JEDNOSTEK LEKSYKALNYCH}

\section{Streszczenie}

Celem niniejszego artykułu jest wypracowanie i przetestowanie modelu znaczenia leksykalnego odnośnie wyrazistości funkcjonalnej składników, tzn. częstotliwości profilowania cech semantycznych w różnych aspektach funkcjonowania słowa: jako element $w$ systemie języka (wyrazistość paradygmatyczna), w kontekście (wyrazistość syntagmatyczna) oraz w tworzeniu jednostek derywacyjnych (wyrazistość derywacyjna). Elementy te - postrzegane jako obiektywne kryteria do oceny ważności cech - używane są do rekonstrukcji organizacji cech semantycznych znaczeń powszechnie występujących nazw zwierząt $\mathrm{w}$ języku angielskim.

Słowa kluczowe: wyrazistość funkcjonalna, znaczenie leksykalne, ważność cechy, profilowanie, nazwy zwierząt 